\title{
CARCASS WEIGHT OF BROILER GIVEN COCONUT MILKY JUICE AND BROWN SUGAR WATER AS DRINGKING WATER
}

\author{
Tabita N. Ralahalu ${ }^{1 *}$, C. Ch. E. Latupeirissa ${ }^{1)}$, Maks A. Tukalpaly ${ }^{2)}$ \\ ${ }^{1}$ Department of Animal Science, Faculty of Agriculture, Pattimura University \\ Jln. Ir. M. Putuhena, Kampus Poka, Ambon 97233 \\ ${ }^{2}$ Alumnus of Agriculture Facult y The Pattimura University \\ *Email : ipopralahalu@gmail.com
}

\begin{abstract}
To produce optimum carcass weight, broiler need an adequate ration which meet their nutrients requirement. The aims of this study were : 1). To examine the effect of giving coconut milky juice and brown sugar water as drinking water on carcass weight and (2). To use by product of coconut milky juice as drinking water. Experimental design used was complete randomized design, with three treatments and five replications. Each replication consists of six chicken. The treatments were P0 (ration + plain water), P1 (ration + coconut milky juice (mature)) and P2 (ration + brown sugar water). Variables measured were: voluntary feed and drinking water intakes, carcass weight and percentage. Analyses of variance were done using the General Linear Model (GLM). Least squares means and standard error were produced. Main effects were detected using LSD. Voluntary intakes were $1805.69 \mathrm{~g}, 1799.14 \mathrm{~g}$, and $1806.66 \mathrm{~g}$ for P0, P1 and P2 respectively. The result shows that the treatments does not affect voluntary intake significantly $(\mathrm{P}>0.05)$. Slaughter and carcass weight of broilers are $1701.33 \mathrm{~g}, 1849.40 \mathrm{~g}, 1847.27 \mathrm{~g}$ and 1263.87 g, 1386.00, 1379.90, for P0, P1 and P2 respectively. Statistical analysis show significant differences $(\mathrm{P}<0.05)$ in slaughter and carcass weight among the treatments in which those parameters are higher for broilers received $\mathrm{P} 1$ and P2 than that of P0. Carcass percentage is the ratio of slaughter and carcass weight, which are 74.27\%, 74.93 and 74.71 for $\mathrm{P} 0, \mathrm{P} 1$ and $\mathrm{P} 2$, respectively. No differences in carcass percentage were obtained $(\mathrm{P}>0.05)$ among the treatments.
\end{abstract}

Key words: Broiler, brown sugar, coconut juice

\section{INTRODUCTION}

Broiler is male or female chicken raised and harvested at the age of $5-6$ weeks to yield meat (Kartasudjana and Suprijatna, 2006 ; Bashir, 2018). Broiler has special features which are grow faster and consume greater amount of food, especially in winter voluntary feed intake tend to increase. High voluntary feed intake result in high feed cost which is about $70 \%$ of production cost. On the other hand, to produce broiler carcass weight that meet SNI requirement need high quality ration. Broiler has been given commercial ration even though in several poultry farms has given one or two additional feedstuff. Because of high consumption and feed cost, it is important to find an alternative to reduce voluntary feed intake without depresses performance.

Brown sugar is an ingredients use in making cakes, snacks, or cooking. In animal husbandry brown sugar is mainly use as source of energy to (DOC) they all chicken. When they are moved from one to other places. Besides used as source of energy, brown sugar also provides other nutrients to enhance performance of broiler. Coconut water is also can be used as source of energy. Coconut water is one of coconut by product, usually use as drink or made into natta de coco. However, most of coconut water is not utilized although, it contain nutrients such as, protein, lipid, carbohydrate and vitamins which are essential to promote growth process and muscle and tissue developments. Because energy is available in brown sugar and coconut water, both can be used to reduce voluntary feed intake. This happen because energy needs is achieved. If the amount of energy an animals requires is achieved the animal will eventually stop eating. In contrast the animal will consume greater amount of food if energy needs has not been achieved.

The objective of this study was to examine the effect of giving coconut milky juice (mature) and brown sugar water as source of available energy on broiler carcass in five weeks.

\section{MATERIALS AND METHODS}

Ninety (90) DOC (day one chick) of broiler, strain Cobb were used, and housed together in litter coop system provided with saw-dust, half wooden wall wire in front. The coop was partitioned into 20 part and 6 chicken were kept in each part. The animals fed on commercial ration BR1, produced by PT. Panca Patriot Prima Sidoarjo. Chemical compositions of the ration were water content $12 \%$, minimum crude protein $21 \%$, minimum crude lipid $6 \%$, maximum crude fiber $5 \%$, energy $3065 \mathrm{kcal} / \mathrm{kg}$, ash $6.5 \%$, calcium $0.9-1.1 \%$, 
phosphor $0.7-0.9 \%$, antibiotic bacitracin Methylene, Disalcylate Coccodiastat Monensin.

The treatments were $\mathrm{P} 0$, drinking water without brown sugar or coconut milky juice (mature), P1, coconut milky juice (mature) as drinking water and P2, drinking water containing brown sugar (1\% of water requirement). An adaption period of 7 days allowed the animals to accustom to feed given and drinking water, and allowed by 5 weeks measurement period. During the experiment the animals were fed twice daily at 07.00 and $16.00 \mathrm{~h}$. The animal had free access to drinking water and feed given was recorded daily. Drinking water feed refusal were weighed every morning before the next feeding.
Variables measured were: voluntary feed and drinking water intakes, carcass weight and percentage. The treatments were imposed in a complete randomized design, 3 treatments in which each treatment was replicated five times. Each replication consist of 6 chicken. Daily voluntary feed and drinking water intake were determined by subtracting feed and water given from feed and water refusal. Slaughter weight was determined by weighing live animals after 10 hours fasting. Carcass weight was determined by subtracting non carcass weight from slaughtered weight. The effects of treatments on voluntary feed intake, carcass weight and percentage were examined by analysis of variance using General Linear Model, Main effect differences were detected using LSD.

Table 1. Average Feed Intake and Water Consumption, Carcass Weight and Carcass percentage of Broiler giving coconut milky juice and brown sugar water

\begin{tabular}{cccccc}
\hline Treatments & $\begin{array}{c}\text { Voluntary feed } \\
\text { intake }(\mathrm{gr})\end{array}$ & Drinking water $(\mathrm{ml})$ & $\begin{array}{c}\text { Slaughter weight } \\
(\mathrm{gr})\end{array}$ & $\begin{array}{c}\text { Carcass weight } \\
(\mathrm{gr})\end{array}$ & $\begin{array}{c}\text { Carcass } \\
\text { percentage } \\
(\%)\end{array}$ \\
\hline P0 & $1805.69^{(\mathrm{a})} \pm 2.74$ & $9118.83^{(\mathrm{b})} \pm 262.30$ & $1701.33^{(\mathrm{b})} \pm 82.40$ & $1263.87^{(\mathrm{b})} \pm 70.75$ & $74.27^{(\mathrm{a})} \pm 0.79$ \\
\hline P1 & $1799.14^{(\mathrm{a})} \pm 9.03$ & $10287.17^{(\mathrm{a})} \pm 329.26$ & $1849.40^{(\mathrm{a})} \pm 77.14$ & $1386.00^{(\mathrm{a})} \pm 66.44$ & $74.93^{(\mathrm{a})} \pm 1.11$ \\
\hline P2 & $1806.66^{(\mathrm{a})} \pm 8.70$ & $9081.83^{(\mathrm{b})} \pm 285.19$ & $1847.27^{(\mathrm{a})} \pm 33.21$ & $1379.90^{(\mathrm{a})} \pm 27.28$ & $74.71^{(\mathrm{a})} \pm 1.74$ \\
\hline
\end{tabular}

${ }_{\mathrm{a}, \mathrm{b}}$ within categories of response, means with different supercsript are significantly different $(\mathrm{P}<0.05)$

\section{RESULTS AND DISCUSSION}

\section{Voluntary Feed Intake}

Voluntary intakes were 1805.69, 1799.14, and $1806.66 \mathrm{~g}$ for P0, P1 and P2 respectively (Table 1). The result show that the treatments does not affect voluntary intake significantly $(\mathrm{P}>0.05)$. Voluntary feed intake of broiler is give in Figure 1. Factors that contribute to voluntary intake are temperature and energy content a ration. Wahju (2004) states that animal will consume large amount of feed if energy content of the ration is low. On the other hand, ration with high energy content will be consumed in small amount. It appears from the present experiment that voluntary intakes are similar among the treatments, because the animals were given same ration which contains $3065 \mathrm{kcal} / \mathrm{kg}$ energy, so this result in contrast with Wahju (2004).

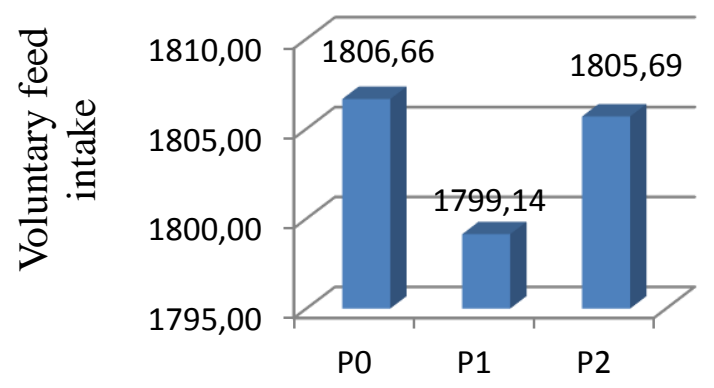

Figure 1. Average Voluntary Feed Intake of Broilers for 5 Weeks
Although voluntary intake was not different significant, numerically voluntary feed intake tends to decrease on treatment P1. This may be because the animals drinks more coconut milky juice (mature) $(10287.2 \mathrm{ml})$ than the others. Coconut milky juice (mature) contains sugars, namely sucrose, glucose, fructose which function as source of energy. So the animals on $\mathrm{P} 1$ have additional energy, this condition makes them full and in turn limit feed intake (only $1799.14 \mathrm{~g}$ ). Feeling full occur because chemical action of nutrient such as carbohydrate which stimulate secretion of cholecystokinine hormone to send signal of full to brain (Benelam, 2009).

However, broilers drank more $(\mathrm{P}<0.05)$ coconut milky juice (mature) (P1), than plain water (P0) or water contains brown sugar (P2). This suggest that broilers have excellent taste in sweet. It appears that coconut milky juice (mature) is sweeter and palatable than the others. This phenomena can be seen from data on Table 1, in which broilers on treatment $\mathrm{P} 0$ consumed drinking water $=9118.83 \mathrm{ml}, \mathrm{P} 1=$ $10287.17 \mathrm{ml}$ and $\mathrm{P} 2=9081.83 \mathrm{ml}$. It is indicated that coconut milky juice (mature) is more palatable than the others, and might be because of nutrient content in the juice particularly sugars content. In general, coconut milky juice (mature) contains $2.6 \%$ sugar (glucose, fructose and sucrose), $0.55 \%$ protein, $0.74 \%$ fat dan $0.46 \%$ mineral (Astawan, 2011). It also appears that high consume of coconut milky juice (mature) does not depress voluntary feed intake of treatment P1. 


\section{Slaughter Weight}

The Slaughter weight data are reported in Table 1. Slaughter weight was significantly higher $(\mathrm{P}<0.05)$ when broiler drank coconut milky juice (mature) (treatment P1) and water containing brown sugar (treatment P2). Slaughter weight of broiler is shown in Figure 2. No differences were obtained in slaughter weight between broiler given coconut milky juice (mature) (P1) and water containing brown sugar (P2). Low slaughter weight of broiler drank plain water (P0) might be caused by low body weight gain during the trial which was $1610.40 \mathrm{~g}$ compare to $1767.63 \mathrm{~g}$ and 3046.20g for P0, P1 and P2, respectively. Blakely and Blade (1991), states that the amount food eaten will influence growth rates and final body weight.

The present result show that plain drinking water does not provide an additional nutrients to support broilers growth as coconut milky juice (mature) or brown sugar do. The presents of different kinds of sugar and minerals (pottasium, sodium, calcium, magnesium, iron, cuprum, phosphor dan sulphur) in coconut milky juice (mature).

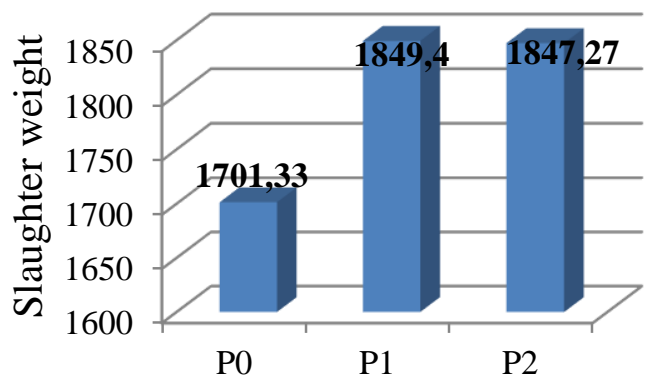

Figure 2. Average Slaughter Weight of Broilers for 5 Weeks

The minerals function as biocatalisator in growth (Tillman et al., 1998). Water containing brown sugar is also contribute to broiler's growth. According to Karnosuhardjo (1981), sucrose is one constituent of carbohydrate found in brown sugar which is about $66.187 \%$, as a source of energy. This shows that brown sugar provides energy to support growth of broiler through out the trial. Live weight in the present study, is higher than live weight of broilers strain Cobb fed on ration containing bay leaf (Syzygium polyanthum wight) for five weeks, which was ranging from $970-1026.7 \mathrm{~g}$ (Suharti et al., 2008). This maybe caused by different treatments. Saponin content in bay leaf may decrease growth by reducing feed intake. This consistence with the finding of Ueda et al. (2004). They found that Saponin in tea leaf limit feed intake which is in turn affects growth.

According to Amrullah (2004) broiler can achieve body weight $1.5-1.9 \mathrm{~kg}$ at the age of $5-6$ weeks. Live weight of broiler Cobb strain is supposed to reach $1.8-2 \mathrm{~kg}$ (Amao et al., 2015 ; Dion, 2017). The current findings indicate that broilers received coconut milky juice (mature) and water containing brown sugar reach maximum live weight for Cobb Strain, which were $1849,40 \mathrm{~g}$ and $1847.27 \mathrm{~g}$ respectively for P1 and P2. In contrast live weight of broilers drunk plain water $(1701,33 \mathrm{~g})$ was lower than supposed live weight of Cobb strain.

\section{Carcass Weight}

Carcass weight of broilers are $1263.87 \mathrm{~g}$, $1386.00 \mathrm{~g}, 1379.90 \mathrm{~g}$ for P0, P1 and P2 respectively. Statistical analysis show significant differences $(\mathrm{P}<$ 0.05 ) in slaughter and carcass weight among the treatments in which those variables are higher for broilers received P1 and P2 than that of P0. Live weight of broiler is reported in figure 3 . This suggests that in coconut milky juice (mature) and water containing brown sugar have nutrients that essential for broilers growth and live weight. Hayse and Marison (1973), point out that factors which influence carcass weight, are age of animal, sex, live weight, size and body conformation of animal, body fat, quality and quantity of a ration and strain use.

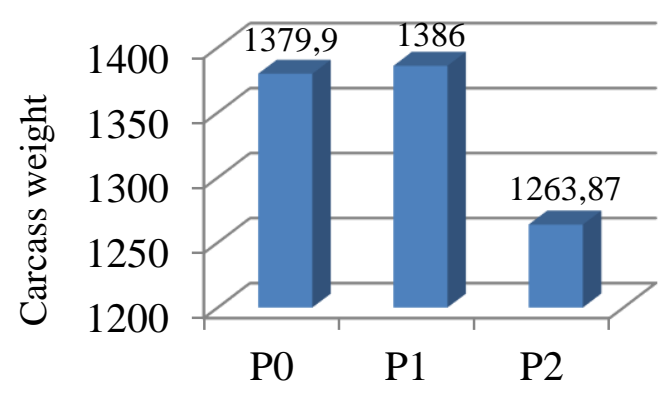

Figure 3. Average Carcass Weight of Broilers for 5 Weeks

In addition, factors that influence carcass weight are type, size, and genetic (Jaturasitha et al., 2004 ; Omojola et al., 2004 ; Abdullah and Matarneh, 2010) state that. On the other hand carcass weight is positively correlated with live weight and non carcass weight. Percentage of non carcass are 25.73, 25.07 and $25.13 \%$ for $\mathrm{P} 0, \mathrm{P} 1$ and $\mathrm{P} 2$, respectively. It may be because the animals in $\mathrm{P} 0$ did not receive an additional nutrients as P1 and P2 which got that nutrient from drinking water.

The result of present study indicates that using coconut milky juice (mature) and water containing brown sugar as drinking water improve feed efficiency. High feed efficiency indicates that feed conversion to yield live weight gain is efficient. Feed conversion specified for broilers Cobb strain is 1.65, while the results are $1.69 ; 0.98$, and 0.90 for $\mathrm{P} 1, \mathrm{P} 2$ and P3, respectively. Based on Standar Nasional Indonesia (2009) carcass weight of broilers in the present study are included in middle to big size carcass, ranging from 1.2 to $1.5 \mathrm{~kg}$. 


\section{Carcass Percentage}

Carcass percentage is the ratio of slaughter and carcass weight, which are $74.27 \%, 74.93 \%$, and 74.71 $\%$ for $\mathrm{P} 0, \mathrm{P} 1$ and $\mathrm{P} 2$, respectively. No differences in carcass percentage were obtained $(P>0.05)$ among the treatments. Carcass percentage of the present study is shown in Figure 4. Karouglu and Durlag (2005), emphasize that carcass percentage is an important factor to evaluate animal productivity (carcass production). Harisshinta, (2009) in Kusuma et al. (2004) affirms that one third of live weight is non carcass weight and its linier with carcass weight and live weight.

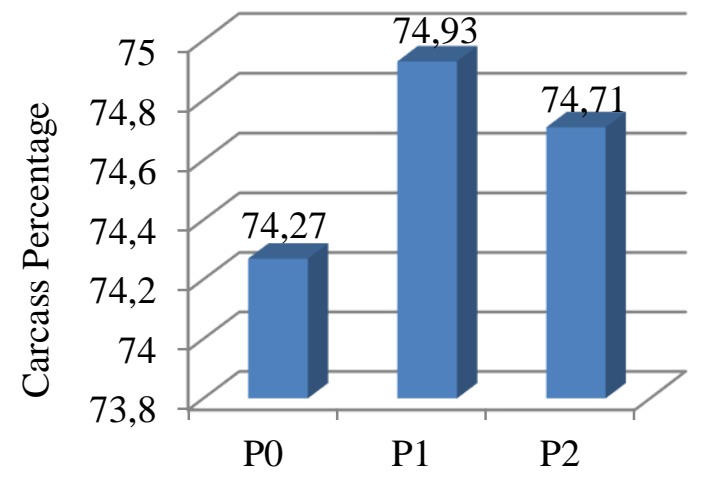

Figure 4. Average Carcass Percentage of Broilers for 5 Weeks

Higher live weight result in higher carcass and non carcass weight. The present study shows that giving coconut milky juice (mature) and brown sugar as drinking water yield similar carcass percentage and non carcass. Agustina (2006) gave herbs in drinking water to broilers and found that carcass percentage was ranging from $67.1 \%-69.1 \%$ for five weeks. The result was lower than that of present study. Even though Saenab et al. (2006) emphasize that carcass percentage of broiler tend to be high when they are given herbs. The similar result also found by Suharti et al. (2008) in which carcass percentage of cobb strain was lower $(56.49-61.62 \%)$ than the result of present study. The differences in carcass weight may be cause not only by strain but also the treatments given. However, carcass percentage of the present study was similar with those of Pratiwi et al. (2016). They found that carcass percentage of broilers fed on different commercial ration ranging from $74.91 \%$ and 73.05 $\%$. The possible reason for that are same strain were used in both trials (Cobb) and ration given contain similar nutrients. Carcass percentage of broilers age 5 6 weeks is 65 - $67 \%$ (Rasyaf, 1995), while according to North and Bell (1992) it is ranging from $65-75 \%$ of body weight.

\section{CONCLUSION}

It can be conclusion that giving $1 \%$ brown sugar in drinking water and coconut milky juice (mature) as drinking water has no significant effect on voluntary intake and carcass percentage. However, giving brown sugar water and coconut milky juice (mature) affect drinking water consumption, slaughter and carcass weight.

\section{ACKNOWLEDGEMENT}

We would like to thank Animal Husbandry Department, Agriculture Faculty for providing facilities for the research works.

\section{REFERENCES}

Abdullah, A. Y., and S. Matarneh. 2010. Broiler Performance and The Effects of Carcass Weight, Broiler Sex, and Postchill Carcass Aging Duration on Breast Fillet Quality Characteristics. The Journal of Applied Poultry Research.19(1): 46-58. DOI: 10.3382/japr.2009-00079.

Agustina, L. 2006. Penggunaan Ramuan Herbal Sebagai Feed Additive Untuk Meningkatkan Performans Broiler. Prosiding Lokakarya Nasional Inovasi Teknologi Dalam Mendukung Usaha Ternak Unggas Berdayasaing. Semarang, 4 Agustus 2006. p. 47-52.

Amao, S. R., L. O. Ojedapo, and O. E. Oso. 2017. Evaluation of Two Commercial Broiler Strains Differing In Efficiency of Feed Utilization. Journal of New Sciences. 14(1): 432-437.

Benelam, B. 2009. Satiation, Satiety and Their Effects on Eating Behaviour. Nutrition Bulletin. 34(2): 126-173.

Amrullah, I. K. 2004. Nutrisi Ayam Petelur. Cetakan ke-3. Bogor: Lembaga Satu Gunung Budi.

Astawan, M. 2011. Mitos dan Fakta Air Kelapa. http://lifestyle.kompas.com>2011/08/11. [13/08/2019: 19.00].

Bashir, M. 2018. Economic Analysis of Broiler Production In Environment Controlled Houses In District Faisalabad. Pakistan Journal of Agricultural Sciences. 55(3): 693695. DOI: $10.21162 / \mathrm{PAKJAS} / 18.5800$.

Blakely, J., and D. H. Bade. 1991. Ilmu Peternakan. Edisi Ke-empat. Penerjemah: B. Srigandono. Yogyakarta: Gadjah Mada University Press.

Dion, A. B. 2017. Info Ternak Unggas: Jenis-Jenis Ayam Broiler (Breed). Dionjuraganternak.blogspot.com>2017/08. [12/08/19: 21.00].

Hayse, P. L., and W. W. Marion. 1973. Eviscerated 
Yield Components Part and Meat Skin Bone Ration In Chicken Broiler. Poultry Science. 52: 718-721.

Jaturasitha, S., R. Khiaosaard, A. Pongpaew, A. Leowtharakul, S. Saitong, T. Apichatsarangkul, V. Leaungwunta, and N. Langani. 2004. The Effect of Strain, Sex, Weight, and Muscle on Fat Quality of Thai Native and Crossbred Chickens (Kai Baan Thai). In: Proceedings of the $42^{\text {nd }}$ Annual Conference. Bangkok, 3-6 February 2005. Bangkok (Thailand): Kasetsart University. p. 137-146.

Karouglu, M., and D. Durlag. 2005. The Influence of Dietary Probiotic (Saccaromy cescerevisiae) Supplementation and Different Slaughter Age on The Performance, Slaughter and Carcass Properties of Broiler. Poult.Sci. (4): 309-316.

Karnosuhardjo, B. I. 1981. Pengaruh Pemberian Gula Merah Terhadap Ayam Pedaging. [Karya Ilmiah Tidak Dipublikasi]. Bogor: Institut Pertanian Bogor.

Kartasudjana, dan Suprijatna. 2006. Pengelolaan Pakan Ayam Kiat Meningkatkan Keuntungan Agribisnis Unggas. Yogyakarta: Kanisius.

Kusuma, R. A., B. Dwiloka, and L. D. Mahfudz. 2004. Berat Karkas, Non Karkas dan Lemak Abdominal Pada Ayam Broiler yang Diberi Pakan Mengandung Salvinea Molista. Animal Agriculture Journal. 3(2): 249-257.

Pratiwi, M., M. A. Pagala, and A. S. Aku. 2016. Produksi Karkas dan Lemak Abdominal Ayam Broiler Strain Cobb dan Strain Lohmann yang Diberi Pakan Berbeda. Jurnal Ilmu dan Teknologi Peternakan Tropis (JITRO). 3(1): 1-6.

North, M. O., and D. D. Bell. 1992. Commercial
Chicken Production Manual. 2 $2^{\text {nd }}$ Edition. Wesport, Conecticut, New York: The Avi Publishing Co. Inc.

Omojola, A. B., A. O. K. Adesehinwa, H. Madu, and S. Attah. 2004. Effect of Sex and Slaughter Weight on Broiler Chicken Carcass. Journal of Food, Agriculture and Environment. 2: 6163.

Rasyaf, M. 1995. Beternak Ayam Pedaging. Cetakan ke 13. Jakarta: Penerbit Swadaya.

Standar Nasional Indonesia. 2009. SNI 3294-2009: Mutu Karkas dan Daging Ayam. Jakarta: Badan Standar Nasional Indonesia.

Saenab, A. B., T. Bakrie, Ramadhan, and Nasrullah. 2006. Pengaruh Pemberian Jamu terhadap Kualitas Karkas Ayam Buras. Buletin Ilmu Peternakan dan Perikanan. 10(2): 133-143.

Suharti, S., A. Banowati, W. Hermana, and K. G. Wiryawan. 2008. Komposisi dan Kandungan Kolesterol Karkas Ayam Broiler yang Diberi Tepung Daun Salam (Syzygium polyanthum wight) dalam Ransum. Media Peternakan. 31(2): 138-145. DOI: 10.5398/medpet.v31i2. 1095 .

Tillman, A. D, H. Hartadi, S. Reksohadiprodjo, S. Prawirokusumo, and S. Lebdosoekojo. 1998. Ilmu makanan Ternak Dasar. Yogyakarta: Gadjah Mada University Press.

Ueda, H., S. Matsumoto, and K. Tanoue. 2004. Growth Response and Crop Emptying In Chicks Force-Fed Diets Containing Various Saponins. The Journal of Poultry Science. 41(4): 298-306. DOI: 10.2141/jpsa. 41.298.

Wahju, J. 2004. Ilmu Nutrisi Unggas. Yogyakarta: Gadjah Mada University Press. 